\title{
EQUITY IN THE USE OF HEMODIALYSIS WITHIN THE NATIONAL HEALTH INSURANCE SCHEME: EVIDENCE JEMBER EAST JAVA
}

\author{
Siti Nafi'atus Salamah',2), Didik Tamtomo3), Endang Sutisna Sulaeman3) \\ ${ }^{1)}$ Dr. Soebandi Hospital, Jember, East Java \\ ${ }^{2)}$ Masters Program in Public Health, Universitas Sebelas Maret \\ 3)Faculty of Medicine, Universitas Sebelas Maret
}

\begin{abstract}
Background: Chronic renal failure is an expensive disease and a public health burden. Previous studies estimated that chronic renal failure causes high healthcare expenditure. The purpose of this study was to examine equity in the use of hemodialysis within the national health insurance scheme.

Subjects and Method: A cross sectional study was carried out at Dr. Soebandi and Kaliwates hospitals in Jember, East Java, in June 2019. A sample of 200 chronic renal failure patients was selected purposively. The dependent variable was hemodialysis use. The independent variables were age, education, health insurance, duration of illness, and severity of disease. The data were collected by medical record and analyzed by a multiple logistic regression.

Results: Hemodialysis use increased with aged $\geq 5$ o years old $(\mathrm{OR}=2.14 ; 95 \% \mathrm{CI}=1.11$ to 4.11; $\mathrm{p}=0.022)$, education $\geq$ Senior high school $(\mathrm{OR}=2.00 ; 95 \% \mathrm{CI}=1.00$ to $3.96 ; \mathrm{p}=$ 0.047), participation in health insurance $(\mathrm{OR}=2.09 ; 95 \% \mathrm{CI}=1.06$ to $4.13 ; \mathrm{p}=0.032)$, duration of illness $(\mathrm{OR}=17.68 ; 95 \% \mathrm{CI}=2.06$ to 151.39 ; $\mathrm{p}=0.009)$, and severity $(\mathrm{OR}=$ 8.99; $95 \% \mathrm{CI}=1.03$ to $78.17 ; \mathrm{p}=0.047)$.

Conclusion: Hemodialysis use increases with aged $\geq 50$ years old, education $\geq$ Senior high school, participation in health insurance, duration of illness, and severity.
\end{abstract}

Keywords: hemodialysis use, chronic renal failure, national health insurance

\section{Correspondence:}

Siti Nafi'atus Salamah. Masters Program in Public Health, Universitas Sebelas Maret. Jl. Ir. Sutami 36A, Surakarta 57126, Central Java. Email: sitinafiatus27@gmail.com. Mobile: 081289434401. 